\title{
Two "Non-Russias"
}

\section{Comparing Belarus and Ukraine}

\author{
Grigory V. Ioffe
}

\begin{abstract}
This paper presents a comparative analysis of Belarus and Ukraine with a focus on the evolution of national self-identity in both countries. It is assumed that their detachment from Russia is an inherent part of this process due to Russia's long-term and overwhelming influence on all aspects of life in the national communities of both countries, including high and popular culture. The author points out that the forms and consequences of this detachment are not predetermined and depend on the structural peculiarities of the areas of Russian influence and on political decisions. The prevailing type of nationalism in both countries also impacts this process. Ethnic nationalism, which is widespread in Central and Eastern Europe, is more explosive and painful than civic nationalism. This analysis is not formalized and is based on field observations. The author admits that having written two monographs (loffe, 2008; loffe, 2014) and numerous articles on Belarus, he is more knowledgeable about Belarus than Ukraine.
\end{abstract}

Key words: Belarus, Ukraine, Russia, national identity, ethnic nationalism, civic nationalism, korenizatsiya (indigenization), Russian World

\section{SIMILARITIES}

Belarus and Ukraine are similar in many ways: Ukrainians are eastern Slavs, just like Belarusians; both languages, Belarusian and Ukrainian, are located in-between Russian and Polish, which in fact are cousins,

Grigory V. loffe is a Professor at Radford University, in Radford, Virginia, U.S. gioffe@radford.edu; (540) 250-3499 
each closer to Belarusian and Ukrainian than to each other. As to the number of identical morphemes, the Belarusian and Ukrainian languages are the closest. Furthermore, Belarusians are mostly Orthodox Christians, just like Ukrainians.

Both countries are sandwiched between Russia and the European Union, or between Brussels and Moscow as centers of power and attraction. For this reason, Belarus and Ukraine have been and still are objects of influence for both parties; not so much influence, though, as encroachments, as inevitable as the air flows from high pressure areas to low pressure ones.

For several centuries proto-Belarusians and proto-Ukrainians, that is, communities with local and regional identities (Rudling, 2014), oscillated between Poland and Russia. Andrew Wilson described the situation of Ukrainians quite clearly. This oscillation, he says, continued for six centuries. Russia's power of attraction prevailed at the turn of the nineteenth and twentieth centuries (Wilson, 2002: 40). As for Belarus, Nina Mechkovskaya stated the same in still more explicit terms: "The problem of cultural and political survival... in the shadow of Russia and Poland has always been a fundamental issue in Belarusian history. This unenviable geopolitical plight might have been a target of Polish or Russian assimilation of two powerful and hostile expansions." (Mechkovskaya, 2003: 61). Another quote from the same author states that as recently as the late nineteenth and early twentieth centuries "everything that rose above the illiterate peasant reality, be it the Church, school, or the powers that be, automatically turned out 'Russian' (and Orthodox) or 'Polish' (and Catholic)" (Mechkovskaya, 2003: 38).

This multi-directional attraction to the centers of power within the common Slavic environment has another side as well. In Belarus and Ukraine, the "national revival" was belated, at least when compared to Russia and Poland. For many centuries Belarusians and Ukrainians matched the term 'demotic ethnie,' which Antony David Smith used to describe ethnic groups that had no upper social strata, because the latter felt that they belonged to the external centers of attraction: either Russia or Poland (Smith, 1986). Considering that nominally Belarusian 
and Ukrainian towns and villages had a large Jewish population, it is clear that both Ukrainians and Belarusians had remained minorities in the larger cities until the beginning of massive urbanization. Elena Gapova believes that this situation is a graphic example of Ernest Gellner's "Ruritania." (Gapova, 2002).

In the 1920s, industrialization in Ukraine and (to a lesser extent) in Belarusled tolarge migrations of the rural population to the bigger cities. Simultaneously, this rural-to-urban movement was accompanied by efforts to enforce a policy of korenizatsiya (indigenization). At Russia's initiative, the Ukrainian and Belarusian languages were promoted on a massive scale in governmental agencies, in the scientific sphere, in the media, in secondary schools, and in some higher educational institutions. However, the Moscow authorities curtailed the campaign when the policy of language indigenization resulted in the tightening of views on history that undermined the idea of a triune Russian people. Another, although not contrasting, explanation for departing from the policy of massive language indigenization links it with the start of industrialization and the Russian authorities' awareness that big-and often multiethnic-workers' groups needed a common language for communication (Rudling, 2014). However, more important for the purposes of our analysis is the view that prevailed during indigenization: Ukraine, like Belarus, began to be viewed as a successor of the European traditions of Kievan Rus and the Grand Dutchy of Lithuania, while Russia was portrayed as a direct descendant of Asian despotic regimes and the usurper of the common East Slavic ethnonym-Russians. Regardless of their historical accuracy, these views matched the purpose of psychological alienation from Russia. In fact, during World War II some native intellectuals in both Ukraine and Belarus collaborated with the Nazis.

It is important to understand, though, that the newly-emerged historical theories were a tool, and not the underlying factor for detachment from Russia. The real cause was rooted in Russia's long-term political, economic and cultural domination, which created a situation when some Belarusians and Ukrainians began to identify themselves with Russia. If this is the case, then detachment from Russia became a means 
of ethnic self-identity for Ukrainians and Belarusians. The only question that remains is the general context and methods of such detachment and, naturally, the expediency of its interpretation that would not entail anger and accusations of outrageous ingratitude. When Russia itself initiated the policy of indigenization, it had a solid ideological basis to rely on-Vladimir Lenin's evaluation of the Great-Russian chauvinism in his article "On the National Pride of the Great Russians." It is hard to imagine a resource as helpful in the modern context.

\section{DISTINCTIONS}

The distinctions between Ukraine and Belarus are nearly as significant as their similarities. Ukraine's population is four times the size of Belarus and its territory is three times larger. Moreover, Ukraine is superior to Belarus in terms of resources, soil fertility, and mineral deposits.

In terms of nationalism, Ukraine became ingrained in the public mind earlier than Belarus. Whereas in Ukraine mature nationalist organizations, such as Mikhnovsky's Revolutionary Ukrainian Party, existed at the very beginning of the twentieth century, in Belarus a unified selfname was established at the end of the 1920s in the east and only in the 1940s in the west of the country. According to therapist Ivan Danilov (Danilov I., 2005), who was born in 1924 and grew up in the Brest Region, even at the end of the 1930s a large share of rural residents continued to call themselves 'tuteishi' (meaning 'locals', Pershai, 2010). This self-name, just like the ability of proto-Belarusians to change their identity depending on who governed their land at the time, was satirized by Belarusian poet and author Yanka Kupala in a self-name tragicomedy, written in 1922 and promptly outlawed by the Soviet authorities.

During World War II, the scale of collaborationism in Ukraine was incomparably greater than in Belarus, where the Nazis had no more than 100,000 paramilitary henchmen. The invaders, too, saw Ukraine as an ethnic entity, while the Nazi occupation authorities realized that the existence of Belarusians was a reality no earlier than 1943, when they allowed the establishment of the Central Rada under Radaslau Astrouski.

After World War II the state security agencies paid unflagging attention to Ukrainian nationalism-fueled dissent. By contrast, 
the Belarusian contribution to dissent is practically unknown, as Alexander Motyl wrote in his 1987 book with the telling title Will the Non-Russians Rebel? (Motyl, 1987: 152).

On the eve of the Soviet Union's breakup, Belarus was more Russified than any other former Soviet republic. Ukraine's east lagged far behind Belarus in that respect. Even in Ukraine's regions east of the Dnieper River, the locals spoke a language that was a tricky blend of Russian and Ukrainian, while in left-bank Ukraine, particularly in Galicia, a variety of Ukrainian close to the literary canon was in everyday use. In Belarus, many people in small towns and rural areas used their own peculiar crossbreed of Russian and Belarusian-Trasianka. At the end of the Soviet era the Russian literary language had already phased out Trasianka, with only a dozen surviving Belarusian words remaining. All that is left of the Belarusian language in Trasianka is pronunciation. Belarus' Trasianka is still criticized by the advocates of "correct" Russian and "correct" Belarusian speech.

Ukraine is a highly-polarized country both culturally and linguistically. In that respect, the Kharkov, Lugansk, and Donetsk regions have far more in common with Russia's Belgorod and Rostov regions and Krasnodar Territory than with Ukraine's western regions. In Belarus, such polarization does not exist, although there are a few differences; western Belarus has been and still is more well-kept than its eastern areas. Catholic churches and cemeteries, and also some features of mansion and park architecture blend amazingly well into the cultural landscape in western Belarus. These features are extremely uncommon in Russian provinces. Moreover, there is no equivalent of Galicia or Crimea in Belarus. In principle, the Grodno Region, with its high number of Catholics (194 Catholic parishes compared to 174 Orthodox ones) and a large share of people who identify themselves as Poles (21.5\%) could resemble Galicia. However, literary Russian prevails there, including in the Polish community. It is also dominant in the capital, Minsk, where a tiny group of intellectuals have shifted to speaking Belarusian as adults.

How frequently and eagerly the Belarusian language is used is clearly seen in a January 2018 Facebook post by Zmitser (Dmitry) Lukashuk, 
a Belarusian-speaking correspondent of Euroradio. A middle-aged man approached Lukashuk on a street in Minsk and asked him for directions. Lukashuk replied in Belarusian. "With every next word the man's confused frown grew stronger," Lukashuk recalls. Lastly, he asked me in surprise and with great suspicion: 'Aren't you Russian?'

'Nope,' was Lukashuk's reply.

'Who are you then?'

'Belarusian!'

'Wait, wait, but I'm Belarusian, too!'

'Take it easy then. You are not Russian, either. So, you can speak normally."

As Lukashuk continues, "The man was dumbfounded. I showed him the right way and left. That's Belarus, you see..."

In the sphere of native mentality or, as it is customary to say these days, identity, the state of affairs in Belarus is very special, too.

The impressions of outside observers match the essence of self-identity in the face of a "significant Other" and thereby are cultural evidence.

Yuri Drakokhrust, a journalist with Radio Liberty's Belarusian service, recalls a story told by his Polish colleague after visiting Minsk. "In a metro underpass she stopped near a stall selling audio CDs. The categories were: Foreign Performers, Russian Performers and Belarusian Performers. She felt puzzled and asked the vendor: 'I see Russian performers are separate from foreign ones. Does that mean that Russia is not a foreign country?'

'Of course not. It's Russia,' the vendor replied.

'Oh, I see. So, Belarus is Russia, right?'

'Of course not. Belarus is Belarus and Russia is Russia.'

The Polish journalist was sincere in her inability to see a solution to the problem where the Belarusian vendor did not see any problem at all. (Drakokhrust, 2017).

"In the Minsk airport I asked a man for a light," Russian journalist Yulia Vishnevitskaya said. "Apparently, he did not quite hear my request and asked me what I was asking him. I repeated the question in English. That guy looked very foreign: about 40 years old, smart eyeglasses, an earring, etc. 
'Of course not, I'm Russian' he said only to slap his forehead the next moment in confusion.

'Wait, wait! What am I tellingyou!I’m Belarusian!'”(Vishnevetskaya, 2010).

It is noteworthy that Minsk is the most Belarusian city in all of Belarus. It is the only place where there is a group of Belarusian speakers, a feature practically absent from other regional centers: Mogilev, Vitebsk, Gomel, Grodno, and Brest.

While no analogues of Galicia exist in Belarus today, with no chance of any appearing in the future, when it comes to counterparts of Crimea and, if you wish, Lugansk, the situation is both far simpler and more complex. It is simpler because in the context of total Russification, all of Belarus may well have the status of such a counterpart. And it is more complex because Alexander Lukashenko has monopolized friendship with Russia politically. This means that the entire legal political opposition is oriented towards the West. A pro-Russian opposition is non-existent as a phenomenon. Attempts to create something like a Russian ethnic movement did take place, but were nipped in the bud. In the current reality, nobody encroaches on the freedom of Belarusians to speak Russian, but that does not mean they want to join Russia, although such a desire did exist in the 1990s. Moreover, such sentiment prevailed in the early 1990s, but began to taper off with the beginning of economic growth in 1996. According to opinion polls, 2002 was the turning point, when Russian President Vladimir Putin invited Belarus to join Russia as six separate regions. This had a sobering effect on Lukashenko and many of his associates. Frequent visits to Russia's neighboring areas, where elementary order and social protection were far worse than in Belarus, fueled and directed this trend, too.

\section{STYLE OF GOVERNANCE}

We now come to another feature that distinguishes Belarus-not only the specifics of its political regime, but also the quality of state governance, which rests upon the responsibility and the national and state interests of all those employed in this sphere. "President Lukashenko has used the factor of Western pressure in a creative way 
to shape a nationally oriented elite, which looks like a unique result in the entirety of post-Soviet space," says Kirill Koktysh, a Russian political scientist at Moscow-based MGIMO University. He believes that the Belarusian ruling elite grew up and matured on more than a decade of Western sanctions, when the very instance of being included in sanction lists served as an external confirmation of how important and irreplaceable a certain official is (Koktysh, 2018).

Indeed, Belarusian civil servants do have their own selfish interests, but to a far more moderate degree than their counterparts in the other two Slavic sister countries. Even politicized Transparency International (TI) has recognized this, albeit after a long delay. For instance, in 2016, Belarus was awarded a relatively low corruption rating of 79th place among world countries, while Russia and Ukraine shared 131st place. The West has tended to look at Belarus through politicized glasses for quite some time. For example, in 2005, Belarus was 105th in the world corruption rankings (Ioffe, 2008: 111-12). Belarus is no longer rebuked for its lack of democracy because geopolitics have become more important since 2014. As a result, the effects of this on the Corruption Perceptions Index quickly became manifest. Moreover, just recently, in 2009, Slovak political scientist Balasz Jarabik said that "disturbing though it may sound, Lukashenko has proven to have greater national responsibility and integrity than the entire Orange elite in Ukraine." (Jarabik, 2009). That Jarabik for a long time had been one of the leading "crusaders" for democracy makes his comment particularly significant and trustworthy.

Ukraine's Lina Klimenko and her co-author employed statistical methods to confirm in 2012 that economic success is the root factor for the positive attitude of Belarusians towards the Lukashenko "regime" (Klimenko and Gherghina, 2012). Yulia Vishnevitskaya, already quoted above, formulated another aspect of this successsocial protection-from a journalist's standpoint. She went to Belarus "with the aim of understanding the enigmatic Belarusian soul, but as a result gained a better understanding of her own."

"What are you doing here?" a driver at a bus station in Minsk asked her. 
"I'm trying to see what makes Belarus different from Russia."

"Then take a look at my car. Do you see what is written here? Airbag. Do you know what that means? It's a safety gadget. That's what makes the difference."

"What that man told me then I would hear many times later: life in Belarus is no worse than in Europe and certainly better than in Russia, Ukraine, or the Baltic countries. The roads are smoother and the streets are cleaner. Lukashenko is a good guy, he works really hard, although sometimes he is too harsh towards small businesses" (Vishnevetskaya, 2010). This is no longer true, though. An important decree on that score was signed on November 23, 2017.

The organization of space and, consequently, land management aesthetics is another aspect of the Belarusian way of life (Gapova, 2017). It catches the eye the moment you cross the Russian-Belarusian or Ukrainian-Belarusian border. "A Russian trying to understand Belarus should make the first trip there by car," says Maria Kucherova, a Russian education expert. "I'm very glad that I crossed the Belarusian border for the first time in a car... Large important-looking white cranes on long red legs strolling leisurely along the roads. Vast fields where the tiniest strip of land is planted with crops. And NO hogweed. Clean roadsides, smooth and strait roads and drivers who... follow traffic rules. White cowsheds and herds of well-groomed cows. At a certain moment I realized that the forests look different too. They are transparent. 'They sing, Belarusians often say. All this taken together can be called a man-made miracle, including the forests cleaned of windfall and dead wood. Amazingly, it turns out the woods can be tidied, too..." (Kucherova, 2017).

It is time for some early conclusions. Ukraine and Belarus have two fundamental similarities and two no less fundamental distinctions.

One similarity is that the cultures of both countries are extremely close to each other and to Russia, which for several centuries had set the standards and rules of high and popular culture. The second similarity is a logical continuation of the first one. To acquire self- 
identity, both Ukraine and Belarus had to dissociate themselves from Russia. Moreover, the deeper the feeling of kinship was, the more resolute was the breakup. Ending relations with a relative is always a more difficult decision than putting an end to a casual acquaintance.

One factor that makes Belarus and Ukraine fundamentally different from each other is this: in Belarus, ethnic nationalism, as a way of distancing Belarus from Russia in value terms based on a cultural and historical Westernism that Russia had allegedly trampled underfoot, was not deeply ingrained in the public mind. In Ukraine, ethnic nationalism was perceived and assimilated by about half of the population. In Galicia, which before 1939 had never been under any Russia-centric jurisdiction, ethnic nationalism was professed by an overwhelming majority of the population. The political regime makes another fundamental distinction. Belarusian sociologist Oleg Manayev in November 2017 told a U.S. conference of Slavists that while in Russia a place in the pyramid of power was a means of self-enrichment, in Ukraine it was the other way around-material wealth determined one's position in the official establishment. Only in Belarus the link between a senior official position and material wealth is not determined as strictly as in the two neighboring Eastern Slavic countries. If one proceeds from the communal and collectivist traditions of the Eastern Slavs as a manifestation of solidarity in a traditional society and a strong association of individual enterprise with foreign greed, then it is easy to surmise that of the three political regimes, the Belarusian one is congruous with the traditional cultural matrix. It is not accidental that Lukashenko's rating is above $60 \%$ not only in Ukraine, which does not have a popular national leader, but also in Russia, where such a leader does exist.

The stark contrast between the current state of affairs in Ukraine and Belarus is a consequence of the above-mentioned distinctions. Firstly, before the large-scale crisis in Ukraine erupted, Belarusian GDP per capita was 2.3 times larger than in Ukraine, while in 1990, on the eve of the breakup of the Soviet Union, is was only 25 percent larger (Korchagin, 2017). In 2011, Vyacheslav Yaroshevich and I arrived at the conclusion that in the post-Soviet years Belarus outperformed 
Ukraine and even Russia by such parameters as GDP growth rates, production and consumption of farm produce per capita, spending on education and healthcare per capita, and average life expectancy and infant mortality. Belarus surpassed Ukraine, although it fell behind Russia in terms of gross income per capita, wages, pensions, and labor productivity (Ioffe and Yarashevich, 2011).

\section{DRIFTING AWAY... BY DIFFERENT ROUTES}

Without delving into the particularities of the intra-Ukrainian conflict, one should note that in Ukraine the desire to drift away from Russia and to do so in the most radical style has become dominant. Suffice it to say that in 2016 trade with Russia accounted for a mere $13.52 \%$ percent of Ukraine's overall foreign trade, whereas in 2010 the share was nearly 32\% (Torgovo-ekonomicheskoye, 2018). Yet people-to-people relationships still exist and many Ukrainians today work in Russia. For example, in January-September 2017, 5.7 million Ukrainian citizens visited Russia (Artemyev, 2018), a number that shows clearly how cruel and unnatural the severing of inter-state ties was. Interestingly enough, at the peak of the Ukrainian crisis in 2014, Robert Kaplan, an authoritative geopolitical expert, said in an article in Time magazine that although democratic ideals are close to many in Ukraine, geographical imperatives make full reorientation of that country towards the West nearly impossible (Kaplan, 2014). Naturally, a storm of criticism from the liberal-progressive camp followed. Downto-earth geography, which brushes aside the West's sacrosanct idol of democracy, is the curse of "progressive humanity." The problem is, though, that the wish to push ahead with a crusade for independence, with the factor of geography blocking the way, stems from the striving for national self-identity, and not democracy as such.

"In Russia, there exist two widely-spread, in fact, conflicting viewpoints on relations between Russia and Ukraine and Russians and Ukrainians. Some argue that Russia should take most of the blame for Ukraine's breakaway from the historical nucleus and for dropping out of the Russian civilizational space. In fact, after the breakup of the Soviet Union, Russia allowed all post-Soviet states to leave and 
neglected the potential of its own 'soft power', thus letting the EuroAtlantists take over. Others maintain that from the very emergence of Ukrainian nationalism in the nineteenth century, Ukrainians have been pressing for 'liberation' from the Russians. In that sense, the anti-Russian sentiment that continued to grow throughout the postSoviet years was a natural extension and development of those trends, which were unable to manifest themselves earlier due to historical reasons. Which viewpoint in your opinion is closer to the truth?" This question was posed recently to Ukrainian political scientist Mikhail Pogrebinsky. Well familiar with Pogrebinsky's political preferences, I had expected an answer very different from the one I heard. "I'd opt for the latter point of view," he said. "Although the former factor played its role as well. Alienation from Russia was an innate feature of the Ukrainian project, which is not surprising, though. The languages are close and a majority of the population have the same religion. The options to choose from are few. Either drift away from the one who is closer and stronger (culturally and in other ways), or, sooner or later become assimilated, which happened to Ukrainians in Russia, including the Kuban River area, where ethnic Ukrainians account for a majority of the population" (Pogrebinsky, 2017).

Pogrebinsky hit the nail on the head. A breakaway from Russia was inevitable, although the way it happened was not predetermined. "This does not mean that Russia had no chance of influencing Ukrainian events for the past 25 years," he believes. "It just did not do that, being very certain 'there's no place for it to go'. As a result, Russia lost Ukraine. It remains to be seen, though, whether it lost just one battle or the entire war. The unpreparedness to recognize the existence of an independent Ukrainian state de facto was a major factor for that defeat." (Pogrebinsky, 2017). Bingo! for Pogrebinsky again.

It would be logical to expect the same estrangement from Russia to happen in Belarus. Media outlets like Regnum and Eurasia Daily have long blamed Belarus for hypocrisy, double dealing, soft Belarusianization (who would think, in Belarus!), let alone parasitism on Russia's charitable credulity. It is true that Belarus has retained Russia as a donor and trading partner, while at the same time the country has been 
trying to maintain relations with the West. Belarus even prosecuted Belarusian writers who write for ultra-patriotic Russian periodicals for calling into question the naturalness of the Belarusian language and statehood. Moreover, Belarus has derived certain benefits from the crisis in Ukraine, won better acclaim on the international stage by providing a venue for international negotiations, and now presents itself to the world community as a donor of stability and a potential host of Helsinki-2. Also, Belarus has benefited from the West's fear of Russia. Western strategists now believe that helping Belarus consolidate its independence is more important than campaigning for democracy in that country. This explains why Belarus is now a recipient of a moderate, but stable flow of funds from the European Union targeted at upgrading infrastructure and training public administration specialists. In addition, the West has realized that controllability of an Eastern European country is no less important than the political orientation of its ruling regime. This conclusion is an immediate effect of comparisons between Belarus and Ukraine. The above-quoted Balasz Jarabik, for instance, says that it is hard to come to terms with Belarus, but once a deal has been clinched, its commitment to the letter and spirit of the agreement is more than guaranteed. With Ukraine it is the opposite. Reaching agreements is easy, but adherence to the agreements can hardly be expected. The reason is simple, Belarus is a state, and Ukraine is not (Kharitonov, 2017).

There is another important consideration. Distancing from Russia may follow along Eastern Europe's traditional track of ethnic nationalism relying on Russophobia, which sometimes takes beastly forms. But such distancing may take the form of civic nationalism in a situation where peaceful coexistence of different images of the future and elements of national memory and even different languages of communication becomes normal. This is precisely the civil track that the efforts to build the edifice of a nation is proceeding along in Belarus, albeit slowly and cautiously. Indeed, the place of the Belarusian language in public discourse may grow, but Russian will remain. The role of the Grand Duchy of Lithuania in the emergence of Belarusians as a nation will be recognized, but the role of the Russian Empire and 
its Soviet reincarnation, as well as the role of the Great Patriotic War, will remain the basic one. The Belarusian People's Republic, which was proclaimed a hundred years ago to last for just about nine months with very few taking note of that, will be considered the first attempt at establishing statehood. Yet no less attention will be paid to the Sixth Conference of the Russian Communist Party (Bolsheviks) cells of the Western Region, which proclaimed the Belarussian Soviet Republic that eventually evolved into an independent Belarus.

\section{CIVIC NATIONALISM MINSK STYLE}

In Belarus, the possible triumph of inclusive civic nationalism may follow the defeat of ethnic nationalism, which failed to earn support from society. In fact, the experience of Belarus maywell be implemented in Ukraine for several reasons. Firstly, Ukraine's self-alienation from Russia has been too harsh and artificial and will require certain kinds of pullbacks and rehabilitation. Secondly, because the elements of civic nationalism are important to restoring peace and accord in Ukraine. It is very unlikely that the national remembrance rules Vladimir Vyatrovich wants to implant will ever bring this about. In Ukraine, there are still many people (even excluding Crimea, Donetsk, and Lugansk) to whom Stepan Bandera is an outsider, while Vladimir Vysotsky, Viktor Tsoi and Mikhail Bulgakov, whom Vyatrovich slammed as "tentacles of the Russian World," match their cultural identity perfectly well.

It is noteworthy that no one in Belarus has a grudge against these "tentacles" or the Russian language. Moreover, Lukashenko is the sole post-Soviet national leader alongside Putin who congratulates veteran Soviet performers in Russia and offers condolences when they die. This custom of his is in accordance with the way ordinary Belarusians think and feel.

Professor Mikhail Minakov of the Kiev Mohyla Academy expressed an explicit and exhaustive opinion about whether the Belarusian experience may be used in Ukraine. Interviewed by Radio Liberty in the summer of 2017, he said, "The Belarusians feel certain historical guilt before all of Eastern Europe and neighboring communities, the guilt of creating 
a rather attractive authoritarian model. But one should remember that when in the second half of the 1990s the Lukashenko regime was just finding its feet, it was not attractive at all. Twenty-five years on we can see that we have not yet achieved the level of the GDP in fixed prices we had in the last Soviet years, while the Belarusians have nearly doubled it. This socio-economic price of freedom and non-freedom is impressive. Of the six Eastern Partnership's member-states, only Belarus controls its entire territory... We've tried to change the rules of the game twice. The revolutionary cycles between 1991 and 2004 and 2005 and 2014 went like this: promises of democracy, freedom and wealth; the rise of the oligarchs, an attempt to establish an authoritarian regime; an uprising, and more promises of democracy. We've been through this cycle twice and have already entered a third one." (Dynko, 2017).

In combination with poverty and unbridled corruption, the oscillations of Ukraine's recent history have caused an exodus of the population. Today it is hard to estimate how many Ukrainians have left the country, because millions have migrated to Russia, Poland, and other countries, including Belarus. All this indicates that the geopolitical pendulum will start moving eastwards sooner or laternot because salvation is there, but by virtue of the inversion logic all revolution cycles follow. Time turns into space, and vice versa. The centuries-long history of East-West fluctuations has hardly dropped out of the genetic code. When the pendulum sways, then the experience of building Belarusian statehood and Belarusian civic nationalism will be in demand and put to use in Ukraine.

For this to happen, though, Belarusian identity must be given a chance to develop on its native soil and call to order Russia's "superpower-minded political scientists," who become hysterical at each manifestation of Belarusian identity and resort to the "abandoned spouse syndrome" to prop up theoretically their views on Belarus. It will be useful to turn to Pogrebinsky's warning again and acknowledge that Belarus is a country that is similar to Russia, yet at the same time different. Ignoring this warning is fraught with not just the risk of not ever seeing the Belarusian experience materialize in Ukraine, but the loss of Belarus entirely. 


\section{Grigory V. Ioffe}

\section{References}

Artemyev, M., 2018. Itogi blokady Donbassa. Forbes, 4 January. Available at: http://www.forbes.ru/biznes/354991-itogi-blokady-donbassa-ukrainskayaekonomika-usilivaet-svyazi-s-rossiey

Danilov, I., 2015. Professor Ivan Danilov: "V 1939 godu ya ne znal slova Belarus." Komsomolskaya Pravda, 17 June. Available at: https://www.kp.ru/daily/26555/3271811/.

Drakokhrust, Yu., 2017. Belorusskie gastarbaitery-zerkalo narodnoi dushi. Tut.by, 17 August. Available at: https://news.tut.by/economics/556290.html

Dynko, A., 2017. Ranei va Ukraine byl papulyarny Putin, Tsyaper-Lukashenka-Ukrainski filosof pra Gistarychnuyu Vinu Belarusi Perad Susedziami. Svaboda, 19 June. Available at: https://www.svaboda.org/a/28564081.html

Gapova, E., 2017. "The land under the White Wings": The romantic landscaping of socialist Belarus. Rethinking Marxism, Vol. 29, No. 1, pp. 173 -198.

Gapova, E., 2002. On Nation, gender, and class formation in Belarus ... and elsewhere in the post-Soviet world. Nationalities Papers, Vol. 30, No. 4.

Ioffe, G., 2008. Understanding Belarus and how Western foreign policy misses the mark. Lanham: Rowman and Littlefield.

Ioffe, G., 2014. Reassessing Lukashenka: Belarus in cultural and geopolitical context. Basingstock: Palgrave MacMillan.

Ioffe, G. and Yarashevich, V., 2011. Debating Belarus: an economy in comparative perspective. Eurasian Geography and Economics, 52, No. 6, pp. 750-779.

Jarabik, B., 2009. Belarus: Are the scales tipping? Madrid: FRIDE, a European Think Tank for Global Action, 3 March. Available at: http://www.fride.org/publication/576/belarus-are-the-scales-tipping

Kaplan, Robert, 2014. Geopolitics and the new world order. Time, 20 March. Available at: http://time.com/31911/geopolitics-and-the-new-world-order/

Kharitonov, S., 2017. Balazs Jarabik: Odni i te zhe oppozitsionery v 2010 godu poluchali dengi i iz Polshi i iz Rossii. Reformation, 3 November. Available at: http://rfrm.io/asoby/balash-yarabik-odni-i-te-zhe-oppozitsionery-v-2010-godu-poluchali-dengi-i-iz-polshi-i-iz-rossii 
Klimenko, L. and Gherghina, S., 2012. Determinants of positive attitudes towards an authoritarian regime: The case of Belarus. Soviet and Post-Soviet Review, Vol. 39, pp. 249-270.

Koktysh, K., 2018. V dukhe Trotskogo. Izvestiya, 30 January 30. Available at: https://iz.ru/702287/kirill-koktysh/v-dukhe-trotckogo

Korchagin, Y., 2017. Reiting stran - byvshikh respublik SSSR po VVP v 2016 godu i v 1990 g. VIPerson, 19 September. Available at: http://viperson.ru/articles/reyting-stran-byvshih-respublik-sssr-po-vvp-v-2016-godu-i-v-1990g

Kucherova, M., 2017. Kak ustroyeno obrazovaniye $v$ Belorussii $i$ chem ono otlichayetsya ot rossiiskogo. Available at: https://mel.fm/blog/mariyakucherova/47095-kak-ustroyeno-obrazovaniye-v-belorussii-i-chem-ono-otlichayetsya-ot-rossyskogo

Mechkovskaya, N. 2003. Belorussky Yazyk: Sotsiolingvisticheskiye Ocherki. Munchen: Verlag Otto Sagner.

Motyl, A, 1987. Will the Non-Russians rebel? Ithaca, NY: Cornell University Press, p. 152.

Pershai, A., 2010. Minor nation: The alternative modes of Belarusian nationalism. East European Politics and Societies, Vol. 24, No 3, pp. 379-398.

Pogrebinsky, M., 2017. Ya predpochitayu govorit ne o Russkom mire. Russkaya Idea, 1 November. Available at: https://politconservatism.ru/interview/yapredpochitayu-govorit-ne-o-russkom-mire-a-o-russkoj-ukraine

Rudling, P., 2014. The rise and fall of Belarusian nationalism, 1906-1931. Pittsburgh: University of Pittsburgh Press.

Smith, A. D., 1986. The Ethnic origin of nations. Malden, MA: Blackwell Publishers.

Torgovo-ekonomicheskoye sotrudnichestvo mezhdu Ukrainoi i Rossiyei. Embassy of Ukraine to Russian Federation, 2018. Available at: http://russia.mfa. gov.ua/ru/ukraine-ru/trade.

Vishnevetskaya, Yu., 2010. Belorussiya sama po Ssebe. Expert Online. Available at: http://expert.ru/russian_reporter/2010/25/belorussiya/.

Wilson, A., 2002. The Ukrainians: Unexpected nation. New Haven: Yale University Press. 